\title{
Pembangunan Perangkat Lunak Pembangkit Jadwal Kuliah dan Ujian Dengan Metode Pewarnaan Graf
}

\author{
Findra Kartika Sari Dewi \\ Program Studi Teknik Informatika, Universitas Atma Jaya Yogyakarta \\ Jl. Babarsari No. 43, Yogyakarta 55281, Indonesia \\ E-mail: findra@staff.uajy.ac.id
}

\begin{abstract}
Class and Exam Schedules Generator Software Development Using Graph Coloring Method. Preparation of class schedules and exams schedules at the Faculty of Industrial Technology, University of Atma Jaya Yogyakarta are done manually, thus requiring much time and energy, besides the possibility of inaccuracies. This research builds Fine Generator Scheduler (Fingers) that automate the preparation of class schedules and exams schedules with the graph coloring method, in which two vertices are adjacent, were given different color to each other. Vertices represent classes, while the color represents the placement of class session on schedule. In the graph coloring method, the color used in is as little as possible. Fingers helped the Faculty of Industrial Technology University of Atma Jaya Yogyakarta in scheduling classes and exams quickly and accurately. If the schedule is not obtained as desired then manual treatment is required to replace the schedules.
\end{abstract}

Keywords: Graph, Coloring, Schedule, Generate, Distribution.

\begin{abstract}
Abstrak. Penyusunan jadwal kuliah dan ujian pada Fakultas Teknologi Industri Universitas Atma Jaya Yogyakarta dilakukan secara manual, sehingga membutuhkan waktu dan tenaga yang banyak, disamping adanya kemungkinan ketidak-akuratan penyusunan. Penelitian ini membangun perangkat lunak Fine Generator of Scheduler (Fingers) yang berfungsi untuk mengotomasi penyusunan jadwal kuliah dan ujian dengan metode pewarnaan graf, dimana dua verteks yang adjacent (diampu dosen yang sama, menempati laboratorium yang sama, mempunyai konsentrasi atau semester yang sama) diberi warna yang berbeda satu sama lain. Verteks merepresentasikan mata kuliah, sedangkan warna merepresentasikan sesi penempatan mata kuliah pada jadwal. Pada metode pewarnaan graf, warna yang digunakan sesedikit mungkin. Fingers membantu Fakultas Teknologi Industri Universitas Atma Jaya Yogyakarta dalam penjadwalan kuliah dan ujian secara cepat dan akurat. Pada Jika jadwal yang didapat tidak seperti yang diinginkan maka dibutuhkan manual treatment oleh program studi berupa penempatan jadwal pada hari dan/atau sesi lain.
\end{abstract}

Kata Kunci: Graf, Pewarnaan, Penawaran, Distribusi, Jadwal.

\section{Pendahuluan}

\subsection{Latar Belakang}

Dewasa ini perkembangan teknologi di dunia semakin pesat, khususnya kemajuan di bidang teknologi informasi. Kemajuan di bidang teknologi informasi tak lepas dari peran serta Program Studi Teknik Informatika yang senantiasa memproduksi tenaga ahli di bidang teknologi informasi. Program studi (Teknik Informatika Universitas Atma Jaya Yogyakarta) 
sudah melakukan aktifitasnya secara terkomputerisasi seperti penerimaan mahasiswa baru, pengisian kartu rencana studi, pembuatan kartu hasil studi, dan lain sebagainya. Tetapi masih ada kegiatan esensial seperti penjadwalan kuliah dan ujian yang masih dilakukan secara manual. Kondisi ini tentu sangat ironis, mengingat banyaknya pemrogram yang seharusnya dapat membantu membangun sistem pembangkit jadwal secara terkomputerisasi.

Untuk menangani masalah tersebut diperlukan suatu sistem yang memadai yang mampu membantu pembentukan jadwal yang masih dilakukan secara manual. Penyusunan jadwal kuliah yang ditangani secara manual membutuhkan waktu yang sangat lama dan mungkin terjadi ketidak-akuratan pada jadwal yang dihasilkan untuk pihak program studi serta mahasiswanya. Sehingga sistem yang dibangun harus mampu mengolah data secara cepat serta akurat.

\subsection{Rumusan Masalah}

Rumusan masalah dalam penelitian ini adalah: (1) Bagaimana mengelola data mata kuliah, dosen, ruang kelas dan laboratorium yang terkait dengan kegiatan kuliah dan ujian? (2) Bagaimana membentuk data penawaran mata kuliah untuk suatu semester? (3) Bagaimana mengimplementasikan metode pewarnaan graf untuk menyelesaikan masalah penjadwalan kuliah dan ujian?

\subsection{Batasan Masalah}

Batasan masalah dalam penelitian ini adalah: (1) Sistem mengelola penjadwalan kuliah dan ujian untuk Program Studi Teknik Informatika dan Program Studi Teknik Industri Universitas Atma Jaya Yogyakarta. (2) Penjadwalan kuliah dan ujian dilakukan untuk semester regular (gasal dan genap). (3) Metode yang digunakan pada pembangkitan jadwal ini adalah metode pewarnaan graf. (4) Pada penjadwalan kuliah dapat diatur hari dan sesi dimana pejabat fakultas tidak mengajar karena adanya jadwal rapat.

\subsection{Maksud dan Tujuan}

Maksud dan tujuan dari penelitian ini adalah: (1) Mendesain dan mengimplementasikan perangkat lunak yang dapat membentuk jadwal kuliah dan jadwal ujian secara terkomputerisasi. (2) Membantu program studi dalam kegiatan penawaran dan penjadwalan kuliah dan ujian secara cepat dan akurat.

\section{Tinjauan Pustaka}

\subsection{Graf}

Graf adalah representasi grafik dalam berbagai masalah yang berkaitan dengan sekumpulan obyek-obyek diskret yang digambarkan sebagai simpul (vertex), dan relasi-relasi biner antar obyek-obyek diskret tersebut yang digambarkan sebagai rusuk (edge). Contoh masalah yang dapat disajikan dalam bentuk graf antara lain peta jalan raya yang menghubungkan satu lokasi dengan lokasi yang lain, skema pertandingan sistem gugur suatu kejuaraan, flowchart (diagram alir) suatu program, dsb. Ketika memodelkan sebuah masalah sebagai suatu graf, seringkali dibutuhkan penambahan informasi lain pada vertex atau edge dalam graf tersebut. Contohnya, pada graf yang menggambarkan jalan raya antar kota, perlu ditambahkan nama pada vertex untuk mengidentifikasikan kota, dan bilangan pada edge untuk menunjukkan jarak antar kota. 


\subsection{Pewarnaan Graf}

Pewarnaan graf (graph coloring) adalah pemberian warna pada vertex sedemikian rupa sehingga tidak ada dua buah vertex yang adjacent (terhubung langsung) memiliki warna yang sama dan penggunaan warna diusahakan sesedikit mungkin. Metode pewarnaan graf banyak digunakan untuk aplikasi penjadwalan, alokasi register pada mikroprosesor, pembagian frekuensi radio dan pengenalan pola. Sebagai contoh adalah pemetaan jalur angkot dalam sebuah kota. Jalur angkot digambarkan dengan garis yang menghubungkan dari satu tempat ke tempat lain.

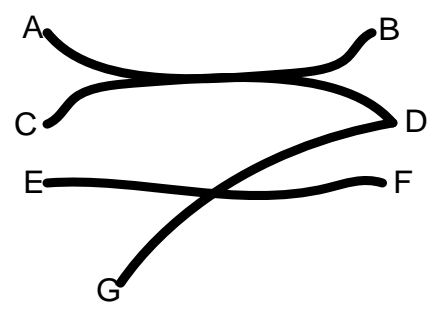

\section{Gambar 1. Jalur angkot}

Pada gambar 1 dapat dilihat ada 4 jalur yang menghubungkan 7 tempat yang berbeda, yaitu A, B, C, D, E, F dan G. Untuk membedakan jalur angkot, caranya adalah dengan mewarnai jalur-jalur tersebut. Jalur yang pertama, yaitu jalur yang menghubungkan A dan B, misalnya warna yang digunakan adalah hitam. Jadi warna jalur tersebut tidak perlu diubah. Selanjutnya jalur yang menghubungkan $\mathrm{C}$ dan $\mathrm{D}$. Lihat pada pertengahan, jalur ini berhimpitan dengan jalur yang pertama. Oleh karena itu, jalur ini tidak boleh memiliki warna yang sama dengan jalur yang berhimpitan dengannya. Hal ini untuk memudahkan pembedaan antara angkot yang jalurnya antara A dan B dengan angkot yang jalurnya antara C dan D. Jadi jalur yang kedua diberi warna lain (digambarkan dengan garis putus-putus pada gambar 2).

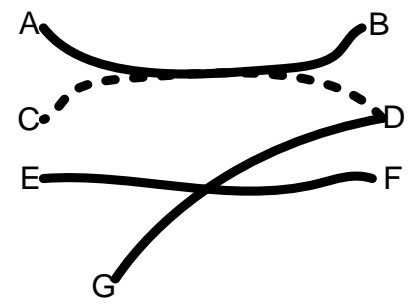

Gambar 2. Pewarnaan jalur angkot 2

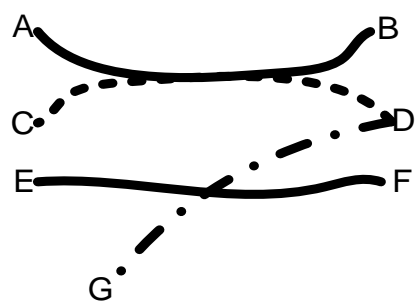

Gambar 3. Pewarnaan jalur angkot 3

Selanjutnya jalur antara D dan G. Lihat bahwa tempat awal yaitu D dihubungkan juga oleh angkot lain dengan C. Oleh karena itu, jalur ini tidak boleh memiliki warna yang sama dengan jalur antara $C$ dan $D$. Selain itu pada pertengahan, jalur ini berpotongan dengan jalur antara E dan F. Oleh karena itu, jalur ini tidak boleh memiliki warna yang sama dengan jalur yang berpotongan dengannya. Lihat gambar 3.

Selanjutnya, jalur terakhir yaitu antara $\mathrm{E}$ dan F. Lihat jalur ini berpotongan dengan jalur antara D dan G, tetapi warnanya sudah berbeda. Sehingga jalur ini tidak perlu diberi perubahan 
warna. Masih ada satu alternatif yaitu pada jalur antara E dan F diberi warna yang sama dengan jalur $\mathrm{C}$ dan $\mathrm{D}$, walaupun hal itu tidak perlu, tetapi hal ini tidak disalahkan, karena jumlah warna yang digunakan tetap sama, yaitu 3 warna. Lihat gambar 4.

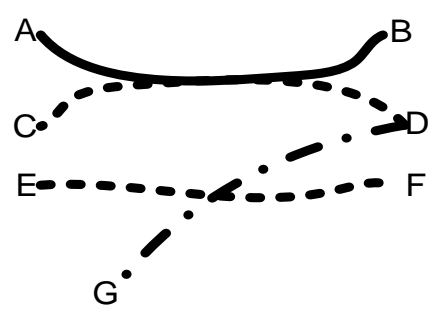

Gambar 4. Pewarnaan jalur angkot 3 alternatif

Gambar 5, 6, 7 dan 8 menggambarkan contoh pewarnaan yang salah karena pemberian warna yang sama pada jalur yang berhimpitan, bercabang dan berpotongan dan pemberian warna yang tidak memperhatikan optimasi jumlah warna.

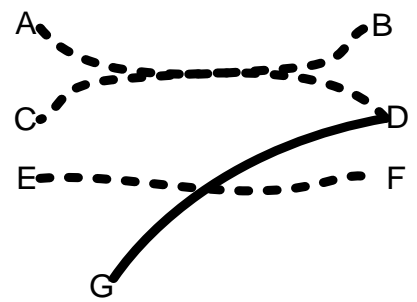

Gambar 5. Warna perhimpitan yang sama

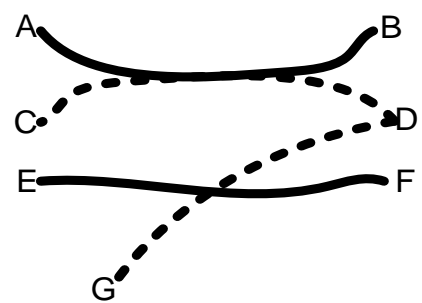

Gambar 6. Warna percabangan yang sama

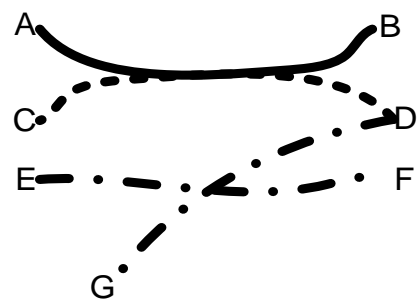

Gambar 7. Warna perpotongan yang sama

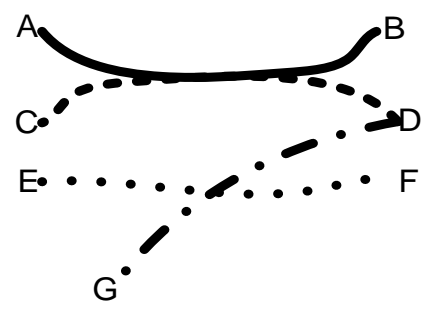

Gambar 8. Warna tidak optimal 
Contoh lain adalah graf pada gambar 9. Pertama vertex A diberi warna hitam. Selanjutnya, perhatikan bahwa vertex $\mathrm{B}$ adjacent dengan vertex $\mathrm{A}$, sehingga vertex $\mathrm{B}$ tidak boleh diberi warna yang sama dengan warna vertex A. Selanjutnya, perhatikan bahwa vertex $\mathrm{C}$ adjacent dengan vertex $\mathrm{A}$ dan vertex $\mathrm{B}$, sehingga vertex $\mathrm{C}$ tidak boleh diberi warna yang sama dengan warna vertex A dan vertex $\mathrm{B}$. Selanjutnya, perhatikan bahwa vertex $\mathrm{D}$ adjacent dengan vertex $\mathrm{B}$ dan vertex $\mathrm{C}$, tetapi tidak adjacent dengan vertex $\mathrm{A}$, sehingga vertex $\mathrm{D}$ tidak boleh diberi warna yang sama dengan warna vertex $\mathrm{B}$ dan vertex $\mathrm{C}$, tetapi harus diberi warna yang sama dengan vertex A agar pengunaan warna dapat optimal. Gambar 10 dan 11 adalah contoh gambar pewarnaan vertex yang salah.

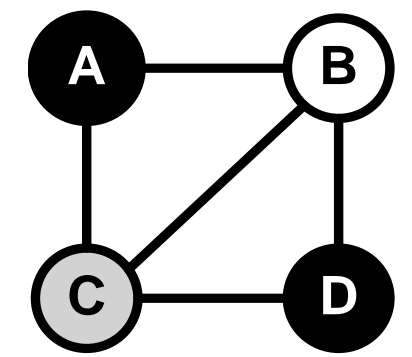

Gambar 9. Pewarnaan Graf

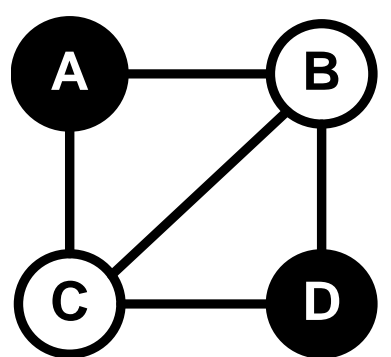

Gambar 10. Pewarnaan Graf - warna adjacent yang sama

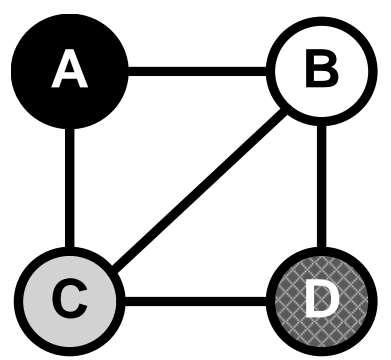

Gambar 11. Pewarnaan Graf - warna tidak optimal

\section{Metodologi Penelitian}

\subsection{Fungsi Produk}

Fungsi produk yang dimiliki Fingers adalah: (1) login, (2) pengelolaan data operator, (3) pengubahan password user, (4) pengelolaan data dosen, (5) pengelolaan data mata kuliah, (6) pengelolaan data konsentrasi, (7) pengelolaan data ruang, (8) pengalokasian laboratorium, (9) penyusunan penawaran mata kuliah, (10) pembentukan jadwal kuliah dan jadwal ujian untuk program studi yang meliputi proses pewarnaan graf dan distribusi jadwal, (11) pelaporan jadwal kuliah dan ujian hasil penjadwalan. Pengguna perangkat lunak ini adalah staf program studi yang berhak melakukan penyusunan penawaran mata kuliah dan penjadwalan kuliah dan ujian, yaitu sekretaris program studi. 


\subsection{Use Case}

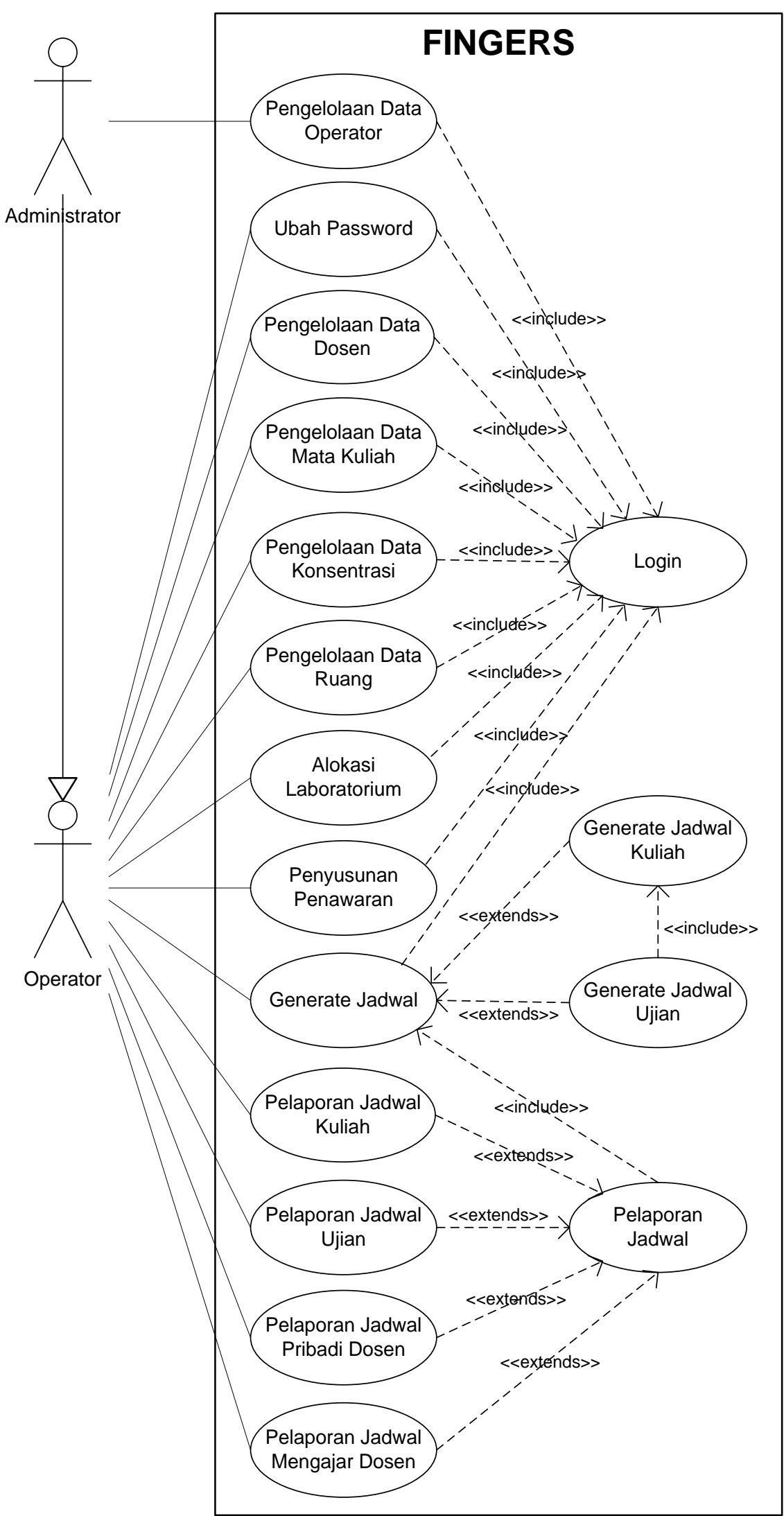

Gambar 12. Use case diagram 


\subsection{Persistent Data}

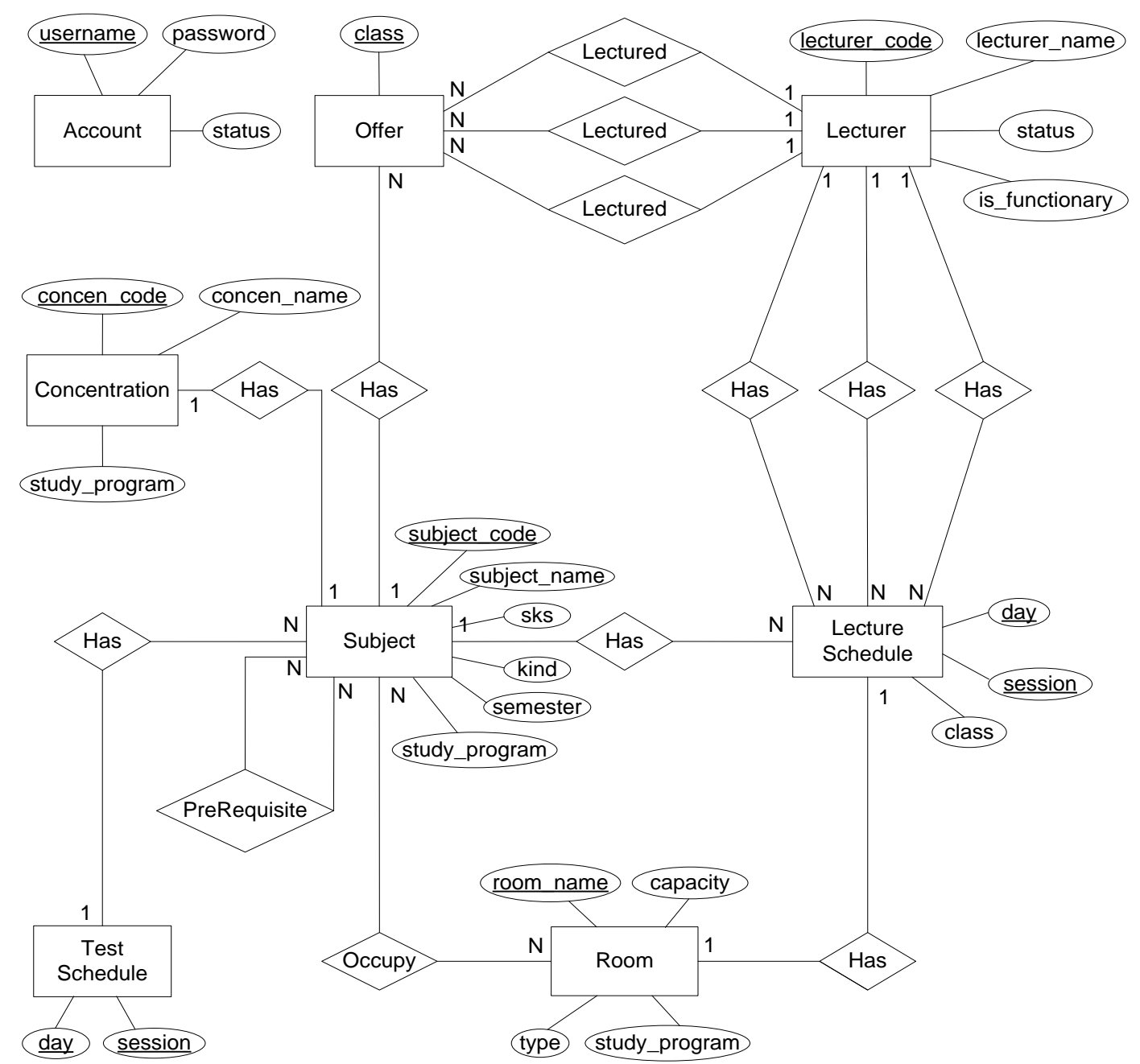

Gambar 13. Entity Relationship Diagram

\section{Pengujian dan Pembahasan}

\subsection{Antarmuka Aplikasi}

\subsubsection{Antarmuka Generate Jadwal}

Antarmuka Generate Jadwal adalah antarmuka yang digunakan untuk membangkitkan jadwal kuliah dan jadwal ujian, dimana didalamnya terjadi proses penjadwalan dengan metode pewarnaan graf. Tab Parameter Jadwal Kuliah digunakan untuk menerima parameter jadwal kuliah yang meliputi waktu kuliah yang dialokasikan, ruang kelas yang boleh digunakan, alokasi laboratorium, dan konstrain berupa jadwal rapat dosen. Tab Parameter Jadwal Ujian digunakan untuk menerima parameter jadwal ujian berupa jumlah hari ujian dan jumlah ruang ujian. Tab File Penawaran Mata Kuliah digunakan untuk menerima berkas penawaran mata kuliah. Berkas yang dimasukkan disini boleh hanya satu berkas saja, untuk salah satu program studi, atau dua berkas sekaligus untuk kedua program studi. Tombol Generate Jadwal digunakan untuk aksi generate jadwal kuliah dan jadwal ujian. Antarmuka Generate Jadwal dapat dilihat di gambar 14 . 


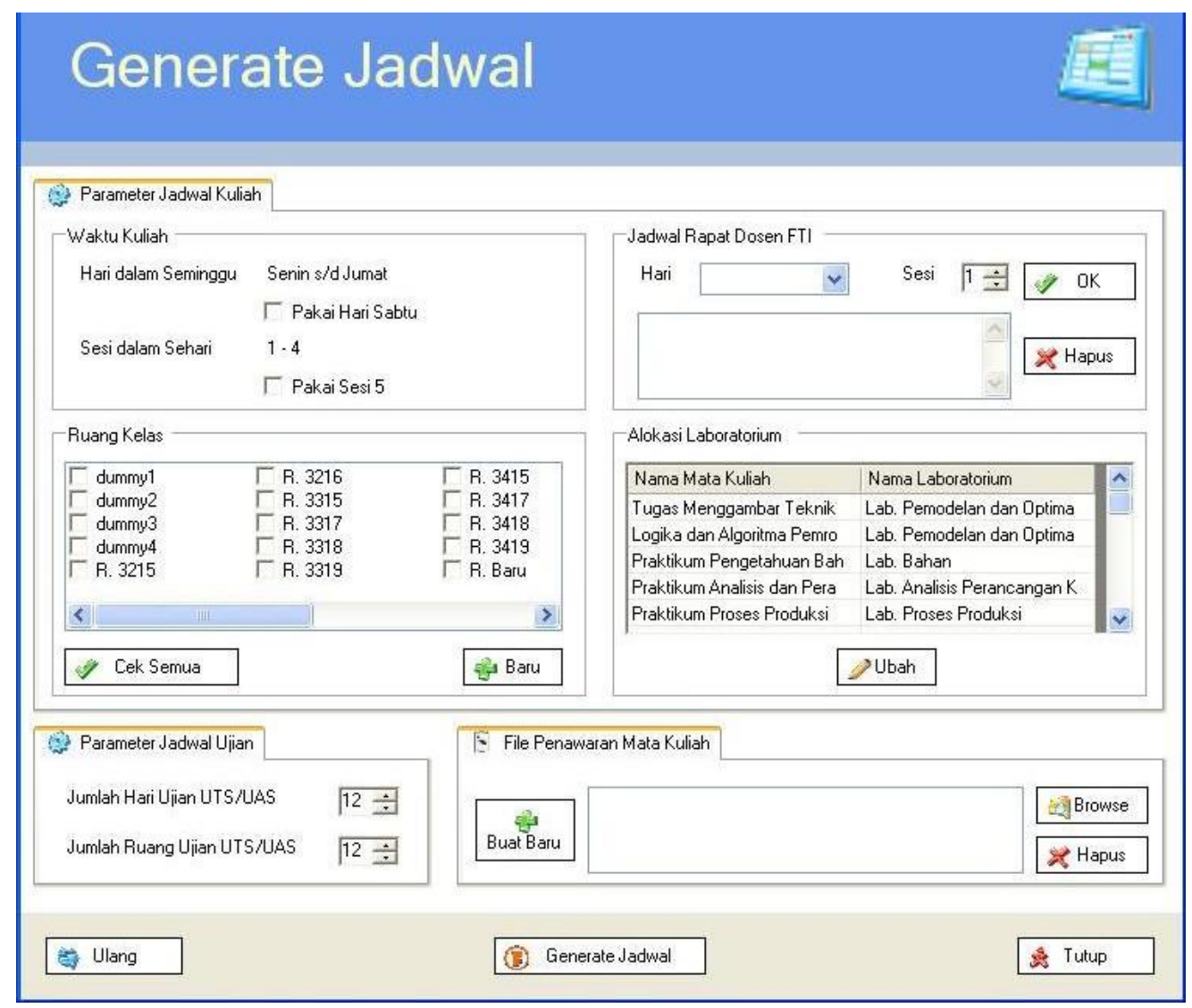

Gambar 14. Antarmuka Generate Jadwal

\subsubsection{Antarmuka Pelaporan Jadwal}

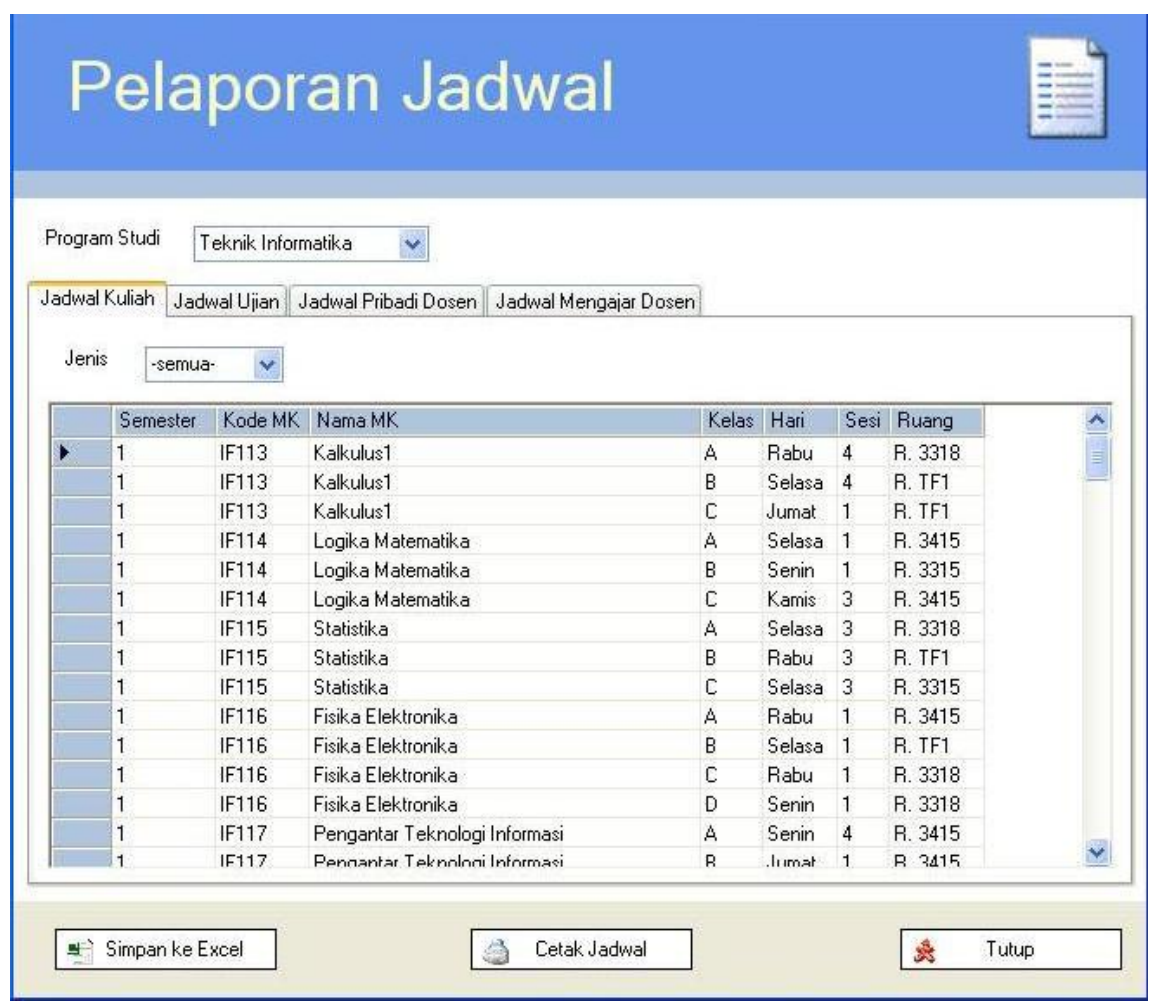

Gambar 15. Antarmuka Pelaporan Jadwal 
Antarmuka Pelaporan Jadwal adalah antarmuka yang digunakan untuk menampilkan jadwal kuliah, jadwal ujian, jadwal pribadi dosen dan jadwal mengajar dosen, menyimpan jadwal-jadwal tersebut dalam file excel serta mencetak jadwal-jadwal tersebut. Ada empat tab yang dapat digunakan pengguna untuk bernavigasi, untuk melihat jadwal yang diinginkan.

\subsection{Pengujian Perangkat Lunak}

\subsubsection{Data Penawaran Mata Kuliah}

Data penawaran mata kuliah merupakan data input, yang disediakan dalam bentuk berkas teks (.txt) dengan format penulisan secara berurutan adalah kode mata kuliah, jumlah SKS, nama mata kuliah, jumlah kelas yang ditawarkan, diikuti dengan kode dosen pengajar sebanyak jumlah kelas yang ditawarkan. Setiap field dipisahkan dengan tanda tab. Berkas penawaran mata kuliah untuk program studi Teknik Informatika dan Teknik Industri dipisahkan, karena perangkat lunak Fingers mendukung pembuatan jadwal untuk salah satu program studi maupun untuk kedua program studi. Ketika jadwal yang ingin dibuat adalah untuk kedua program studi maka kedua berkas akan dipilih sebagai data masukan.

Tabel 1. Penawaran Mata Kuliah Teknik Informatika

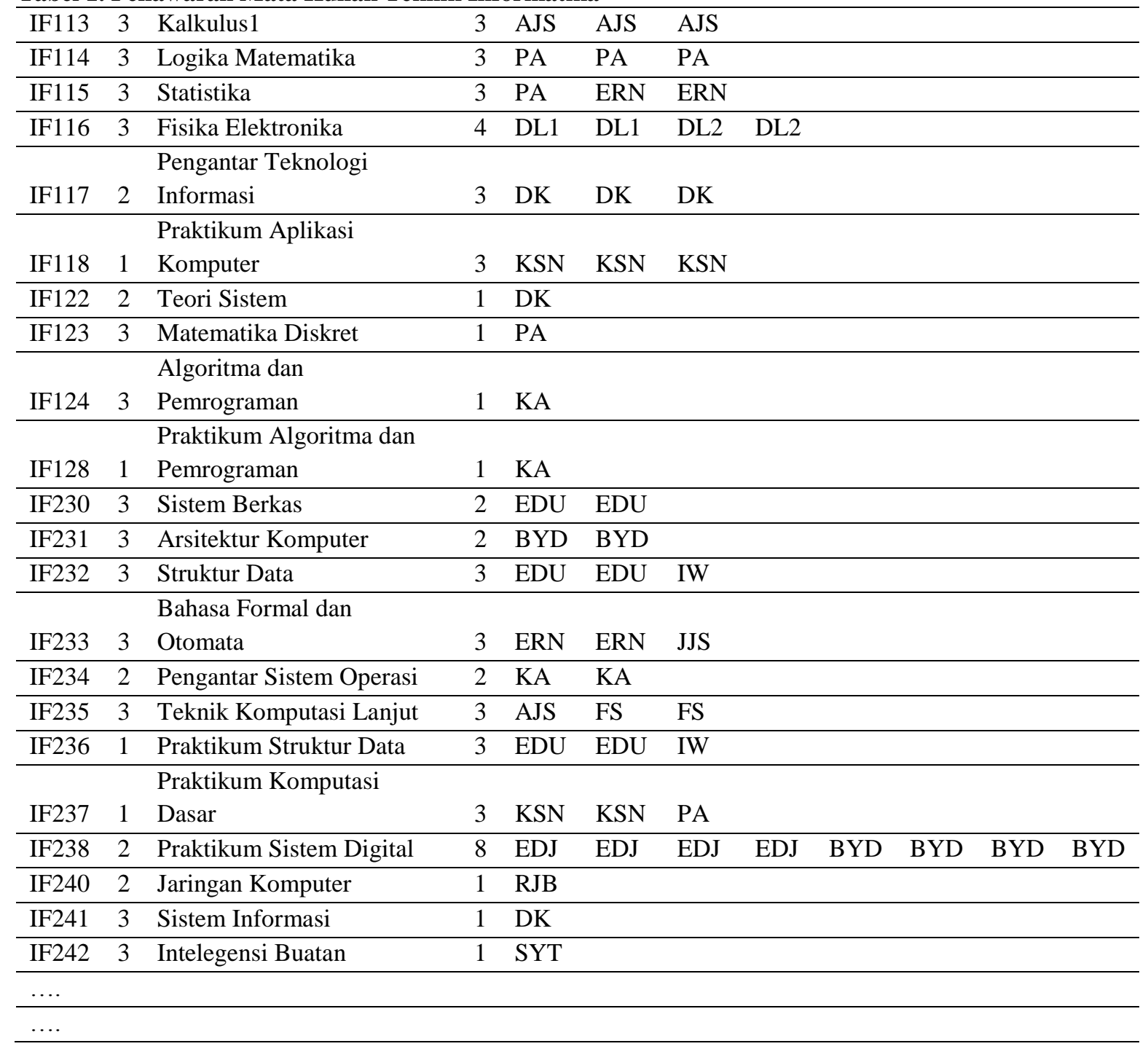




\subsubsection{Data Jadwal Kuliah dan Ujian}

Dari antarmuka Generate Jadwal, setelah pengguna menekan tombol Generate Jadwal, maka akan dihasilkan data jadwal. Jadwal yang dihasilkan adalah jadwal kuliah dan jadwal ujian. Keduanya adalah berkas yang terpisah, sehingga jika parameter masukan adalah data penawaran mata kuliah untuk program studi Teknik Informatika dan Teknik Industri, maka keluarannya adalah 4 berkas yakni jadwal kuliah untuk masing-masing program studi dan jadwal ujian untuk masing-masing program studi.

Tabel 2. Jadwal Ujian Teknik Informatika

\begin{tabular}{|c|c|c|}
\hline \multicolumn{3}{|l|}{ Hari ke-1 } \\
\hline 1 & IF124 & Algoritma dan Pemrograman \\
\hline & IF242 & Intelegensi Buatan \\
\hline 2 & & \\
\hline 3 & IF435 & Sistem Informasi Enterprise \\
\hline 4 & IF355 & Komputer dan Masyarakat \\
\hline Hari ke-2 & & \\
\hline 1 & IF231 & Arsitektur Komputer \\
\hline 2 & IF354 & Ekonomi Teknik \\
\hline 3 & IF117 & Pengantar Teknologi Informasi \\
\hline 4 & IF415 & Aplikasi Wireless/Mobile \\
\hline & UN470 & Kuliah Kerja Nyata/KKN Informatika \\
\hline Hari ke-3 & & \\
\hline 1 & & \\
\hline 2 & & \\
\hline 3 & IF230 & Sistem Berkas \\
\hline 4 & IF356 & Interaksi Manusia dan Komputer \\
\hline Hari ke-4 & & \\
\hline 1 & IF113 & Kalkulus1 \\
\hline 2 & & \\
\hline 3 & & \\
\hline 4 & & \\
\hline Hari ke-5 & & \\
\hline 1 & & \\
\hline 2 & & \\
\hline 3 & IF233 & Bahasa Formal dan Otomata \\
\hline & IF351 & Basis Data \\
\hline 4 & UN110 & Pendidikan Agama \\
\hline Hari ke-6 & & \\
\hline 1 & & \\
\hline 2 & IF433 & Penambangan Data \\
\hline 3 & & \\
\hline 4 & & \\
\hline Hari ke-7 & & \\
\hline 1 & & \\
\hline 2 & & \\
\hline 3 & IF352 & Grafika Komputer \\
\hline 4 & IF244 & Manajemen Industri \\
\hline$\ldots$ & & \\
\hline
\end{tabular}


Untuk data jadwal kuliah, format penulisan secara berurutan adalah hari (senin s/d jumat atau sabtu - sesuai pilihan pengguna), ruang kelas/laboratorium (sebagai kolom), sesi kuliah (sebagai baris), dan nama mata kuliah (kelas) sebagai isinya. Sedangkan untuk jadwal ujian, format penulisan secara berurutan adalah hari, sesi, kode mata kuliah, dan nama mata kuliah. Contoh jadwal ujian dapat dilihat di tabel 2.

Setelah jadwal kuliah dan jadwal ujian terbentuk, tersedia menu untuk membuat jadwal lain yakni jadwal mengajar dosen dan jadwal pribadi dosen. Formatnya sama dengan jadwal kuliah, namun untuk jadwal mengajar dosen, isi tabel bukan nama mata kuliah dan kelasnya, melainkan nama dosen, sedangkan untuk jadwal pribadi dosen, isi tabelnya tetap nama mata kuliah dan kelasnya, namun yang ditampilkan hanya mata kuliah yang diampu oleh dosen yang bersangkutan.

Jika jadwal yang dihasilkan tidak memenuhi keinginan program studi (dalam hal susunan sesi kuliah), maka jadwal dapat diubah secara manual dengan cara menukar (swap) sekelompok mata kuliah yang dilaksanakan pada satu sesi kuliah dengan sekelompok mata kuliah yang dilaksanakan pada sesi kuliah yang lain atau dengan cara menempatkan jadwal mata kuliah pada hari dan/atau sesi lain yang sesuai.

Demikian juga untuk jadwal ujian, jika hari ujian yang dibutuhkan melebihi hari yang disediakan, maka pihak program studi bertugas untuk memilih mata kuliah mana saja yang diujiankan pada sesi yang sama. Hal tersebut tidak ditangani oleh Fingers karena Fingers menghasilkan jadwal ujian yang sesuai dengan jadwal kuliah, sehingga tidak akan ada tabrakan jadwal ujian pada mata kuliah yang jadwal kuliahnya tidak bertabrakan. Pemilihan mata kuliah yang diujiankan pada sesi yang sama (ditabrakkan) membutuhkan pertimbangan program studi.

\section{Kesimpulan}

Kesimpulan yang dapat ditarik dari penelitian ini adalah: (1) Metode pewarnaan graf dapat digunakan untuk penyusunan jadwal kuliah dan jadwal ujian dengan peraturan pewarnaan verteks yang mempertimbangkan jenis mata kuliah, semester mata kuliah, dosen pengampu dan ruang yang digunakan. (2) Fingers mampu menangani tugas program studi untuk melakukan penjadwalan kuliah dan ujian serta menangani pengelolaan data-data yang berhubungan dengan penawaran dan penjadwalan mata kuliah. Jika tugas ini dikerjakan secara manual, maka dibutuhkan waktu dan pemikiran yang tidak sedikit serta ada keraguan dalam hal akurasi, namun dengan menggunakan Fingers tugas tersebut dapat diselesaikan dengan mudah, cepat dan akurat. (3) Perangkat lunak Fingers dapat dikembangkan dengan menambah fasilitas pemilihan hari dan sesi dimana dosen tidak bisa mengajar dan fasilitas penentuan jumlah ruang ujian yang dibutuhkan untuk masing-masing kelas mata kuliah.

\section{Saran}

Untuk pengembangan lebih lanjut, beberapa saran yang yang perlu adalah sebagai berikut: (1) Perangkat lunak Fingers dikembangkan dengan menambah fasilitas pemilihan hari dan sesi dimana dosen tidak bisa mengajar dan fasilitas penentuan jumlah ruang ujian yang dibutuhkan untuk masing-masing kelas mata kuliah. (2) Perangkat lunak Fingers dikembangkan supaya dapat membangkitkan jadwal kuliah dan ujian untuk program studi lain sesuai karakteristik program studi.

\section{Referensi}

Boggs, W., Boggs, M. 2002. Mastering UML With Rational Rose. New York: Sybex.

Dewi, F.K.S. 2005. Laporan Kerja Praktek Pembangkit Jadwal dengan Metode Pewarnaan Graf. Yogyakarta: Universitas Atma Jaya Yogyakarta. 
Dharwiyanti, S., Wahono, R.S. 2005. Pengantar UML, (Online), (http://ilmukomputer.org/ 2006/ 08/25/pengantar-uml/, diakses 02 Juni 2005).

Fowler, M., Scott, K. 1999. UML Distilled - Second Edition. Massachusetts: Adisson Wesley.

Jacobson, I., Booch, G., Rumbaugh, J. 1998. The Unified Software Development Process. Massachusetts: Addison-Wesley.

NIIT. 2003. Introduction To Unified Modeling Language. New Delhi: Sona Printers Pvt Ltd.

Schach, S.R. 2004. An Introduction to Object-Oriented Systems Analysis and Design with UML and the Unified Process. New York: Mc Graw-Hill.

Sinaga, B.L. 2002. Diktat Kuliah Rekayasa Perangkat Lunak. Yogyakarta: Universitas Atma Jaya Yogyakarta.

. Graph Coloring Method, (Online), (http://mat.gsia.cmu.edu/COLOR/, diakses 02 Juni 2005).

Graph Coloring, (Online), (http://www.cs.ualberta.ca/ joe/Coloring/, diakses 02 Juni 2005). 